\title{
Towards Redirecting the Female Circumcision Debate: Legal, Ethical and Cultural Considerations
}

\author{
Angela Wasunna*†, LL.B.
}

The World Health Organization reports that between 100 and 137 million women, mostly in Africa, have undergone some form of female circumcision $(1,2)$ (also referred to as female genital mutilation). Female circumcision is practiced in more than twenty African countries (Table 1) as well as in Oman, South Yemen, and the United Arab Emirates. Moslem populations of Indonesia and Malaysia also practice circumcision (2). Despite regional variation in its prevalence, female circumcision is more accurately considered an ethnic practice with no direct relation to political or geographical boundaries; for example, in Kenya, the Meru practice excision, whereas the Luo do not; in Nigeria, the Yoruba, Ibo and Hausa practice excision but the Nupes of Fulani do not (3).

This paper is an attempt to redirect the debate against female circumcision. The paper questions the legality of enacting criminal sanctions against female circumcision in western nations, while permitting other similar practices. To this end, the paper examines the historical and cultural context of the practice and, further, draws parallels between this procedure, male circumcision, and other forms of surgery. The paper investigates some international legislative responses to female circumcision. The paper further explores the "doublestandard" application of laws in western countries that have a high immigrant presence, in the context of female circumcision, and concludes by examining what direction the law should take in this debate. The position of the author is that although female circumcision is a medically unacceptable practice, the use of criminal law in western countries is nevertheless

\footnotetext{
* To whom correspondence should be addressed: P.O. Box 95735 , Mombasa, Kenya, East Africa. E-mail: awasunna@mailcity.com.

$\dagger$ Graduate Law Program, Harvard Law School, Cambridge, MA.
}

hypocritical and redundant. The most effective way to end female circumcision in its entirety is through aggressive education and the creation of alternatives for communities affected by the practice.

\section{ORIGINS OF FEMALE CIRCUMCISION}

The origins of female circumcision are obscure but the practice most likely dates back thousands of years. Herodotus reported that female circumcision took place in ancient Egypt during the fifth century B.C. and there is also evidence that early Romans and Arabs had adopted the practice (for review, see 3). At some uncertain point in history, excision practices became associated with the obsessive preoccupation with virginity and chastity that still characterizes many African and Arab cultures today; this combination resulted in the more radical practice of infibulation (3) (for description of procedures, see Box 1).

Giorgis has suggested that the origin of female circumcision can be traced to the patriarchal family system, in which a woman could have only one husband while a man could have several wives (4). Along with other elaborate formal and informal sanctions, strong patriarchal systems fostered female circumcision, therein restricting women's sexuality for the preservation of the male's lineage.

Another explanation is offered by the Egyptian pharaonic belief in the bisexuality of the gods:

\footnotetext{
Now, just as certain gods are believed to be bisexual, so every person is believed to be endowed with the masculine and feminine "souls". These souls reveal their respective physiological characteristics in and through the procreative organs. Thus, the feminine soul of the man is in the prepuce, whereas the masculine soul of the woman is situated in the clitoris. This means that as the young boy
} 
grows up and is finally admitted into the masculine society, he has to shed his feminine properties. This is accomplished by the removal of the prepuce, the feminine portion of his original sexual state. The same is true with a young girl, who upon entering the feminine society is delivered from her masculine properties by having her clitoris or her clitoris and her labia excised. Only thus circumcised can the girl claim to be fully a woman and thus capable of the sexual life (from p. 271 in reference 5).

Excision and infibulation are by no means unique to Africa, and have at some time in history been practiced and are indeed still practiced in several parts of the world. Female clitoral excision was practiced in the English-speaking world during the 19th century $(6,7)$. One reason that has been provided for its practice in the West is denoted in the following passage:

Isac Baker Brown (1812 - 1873) was considered one of the ablest and most innovative gynecological surgeons in England. ... Dr. Brown was seeking a surgical solution to cure the vexing mental disorders of women. According to the doctor, the main culprit was masturbation. The treatment was clitoridectomy (from p. 173 in reference 8; see also reference 9 ).

American physicians not only adopted clitoridectomy, but they also extended the scope of the operation to include oophorectomy (i.e. removal of the ovaries) (10). Lesbian practices, suspected lesbian inclinations, and an aversion to men were all treated by clitoral excision (5), as were hyper-sexuality, hysteria and nervousness (8). Until 1905, labia were infibulated in the United States to prevent masturbation (11) and this type of surgery was reportedly performed in mental hospitals as late as 1935 (12).

Historically then, female circumcision has not been an exclusively Arab/African phenomenon. But why did the practice take root and survive in certain societies and not in others?

\section{WHY FEMALE CIRCUMCISION CONTINUES TODAY}

What are the forces that drive people in the 20th Century, in this age of technological advancement and knowledge, to still succumb to this practice? The most common response is tradition. Considering the question more carefully, the main reasons for the continuation of female circumcision may be loosely classified into four categories: 1) psychosexual, 2) religious, 3) sociological, as well as 4) hygienic and aesthetic reasons (13).
Table 1. Female genital mutilation in Africa $^{a}$

\begin{tabular}{|c|c|c|}
\hline Country & $\begin{array}{c}\text { Estimated } \\
\text { prevalence }(\%)\end{array}$ & $\begin{array}{c}\text { Number of } \\
\text { women }(\mathbf{x 1 0 0 0})\end{array}$ \\
\hline Benin & 50 & 1,370 \\
\hline Burkina Faso & 70 & 3,650 \\
\hline Cameroon & 20 & 1,330 \\
\hline Central African Republic & 43 & 740 \\
\hline Chad & 60 & 1,930 \\
\hline Côte d'Ivoire & 43 & 3,020 \\
\hline Djibouti & 98 & 290 \\
\hline Egypt & 80 & 24,710 \\
\hline Eritrea & 90 & 1,600 \\
\hline Ethiopia & 85 & 23,240 \\
\hline Gambia & 80 & 450 \\
\hline Ghana & 30 & 2,640 \\
\hline Guinea & 50 & 1,670 \\
\hline Guinea-Bissau & 50 & 270 \\
\hline Kenya & 50 & 7,050 \\
\hline Liberia & 60 & 900 \\
\hline Mali & 75 & 4,110 \\
\hline Mauritania & 25 & 290 \\
\hline Niger & 20 & 930 \\
\hline Nigeria & 50 & 28,170 \\
\hline Senegal & 20 & 830 \\
\hline Sierra Leone & 90 & 2,070 \\
\hline Somalia & 98 & 4,580 \\
\hline Sudan & 89 & 12,450 \\
\hline Togo & 50 & 1,050 \\
\hline Uganda & 5 & 540 \\
\hline United Republic of Tanzania & 10 & 1,500 \\
\hline Zaire & 5 & 1,110 \\
\hline Total & & 132,490 \\
\hline
\end{tabular}

a Reproduced from reference 2; refer to original source for additional information and methods of estimation.

\section{Psychosexual Factors}

A common belief in countries where female circumcision is prevalent is that the clitoris is an aggressive organ, threatening the male organ (14) and even endangering the baby during delivery (15). Alternatively, because the focus of sexual desire is recognized to be the clitoris, many cultures believe that excision is necessary to protect the woman against her over-sexed nature, saving her from temptation, suspicion and disgrace while preserving her chastity $(3,4,16)$. These beliefs must be understood in the context of societies where virginity (for a woman) is an absolute pre-requisite for marriage and where an extramarital relationship provokes the most severe penalties. In addition, in both Sudan and Egypt, female circumcision is believed to increase male sexual pleasure during intercourse (17).

\section{Religious Factors}

As alluded to above, female circumcision is a practice that transcends cultural, religious, and political boundaries though it is clearly more common today 


\section{Box 1. The Procedures}

At the physical level, female circumcision cannot be equated to male circumcision since the former generally involves far more extensive and permanent damage to the sexual organs and frequently has significant effects on the health of the individuals subjected to it (see text). This is part of the reason why female circumcision is abhorred, unlike male circumcision where the debate centers on stress to the infant, with relatively few people decrying its long-term effects.

\section{Types of Female Circumcision ${ }^{\mathrm{a}}$}

\begin{tabular}{|c|c|}
\hline Mild Sunna & $\begin{array}{l}\text { Pricking, slitting, or removal of the prepuce of the clitoris causing relatively little if any } \\
\text { damage. "Sunna" is an Arabic word meaning "tradition". }\end{array}$ \\
\hline Modified Sunna & Partial or total excision of the body of the clitoris. \\
\hline Clitoridectomy / Excision & $\begin{array}{l}\text { Removal of part or all of the clitoris and part or all of the labia minora. The vaginal opening } \\
\text { is often occluded by the extensive scar tissue that results from the procedure. }\end{array}$ \\
\hline Infibulation / Pharaonic circumcision & $\begin{array}{l}\text { Consists of clitoridectomy and the excision of the labia minora and the inner layers of the } \\
\text { labia majora. The raw edges are subsequently sewn together with catgut or made to adhere } \\
\text { to each other by means of thorns. This causes the remaining skin of the labia majora to } \\
\text { form a bridge of scar tissue over the vaginal opening. A small sliver of wood or straw } \\
\text { inserted into the vagina prevents complete occlusion and thereby leaves a passage for urine } \\
\text { and menstrual flow. }\end{array}$ \\
\hline Introcusion & Enlargement of the vaginal opening by tearing it downward. \\
\hline Intermediate & $\begin{array}{l}\text { Modified version of pharaonic circumcision consisting of removal of the clitoris and part } \\
\text { of the labia minora but leaving the labia majora intact. Suturing with catgut then narrows } \\
\text { the introitus. }\end{array}$ \\
\hline Recircumcision or refibulation & $\begin{array}{l}\text { Performed on women who have given birth, or who are widowed or divorced to simulate } \\
\text { a virginal vagina. The procedure is called "adla" (tightening) and is most frequently } \\
\text { performed on women who have had previous pharaonic or intermediate circumcisions. The } \\
\text { edges of the scar are pared and sewn together, or the loose tissue is stitched. Refibulation } \\
\text { is sometimes referred to as "Adlat El Rujal" meaning men's circumcision as it is designed } \\
\text { to create greater sexual pleasure for the man. }\end{array}$ \\
\hline
\end{tabular}

a modified from reference 3 ; see also reference 2

Traditional practitioners of female circumcision vary among different ethnic groups. Apart from midwives, barbers may perform the procedure, as is the case in Egypt and Northern Nigeria. In Northern Zaire the traditional circumciser is a male priest. Instruments used include razor blades, scissors, knives, thorns and pieces of glass. Antiseptic and anesthetics are not usually used although medicinal herbs would be used to assist the healing process or to help clot the blood. The main procedures are tabulated below.

within certain groups. The custom of female circumcision does not appear to have originated in Islam, but has been accepted by it. It is believed that clitoridectomy was an original African institution adopted by Islam at the conquest of Egypt in 742 A.D. (18). Though it is worth noting that female circumcision is not practiced in most Islamic countries and, in fact, it is not in accordance with the Koran $(19,20)$.

\section{Sociological Factors}

Female circumcision is viewed by many as a way of socializing female fertility and forming an initiation rite of development into adulthood (3). In many parts of
Africa, elaborate ceremonies surround the practice. The event is filled with symbolic song, dance and chants intended to teach the young girl her duties and desirable characteristics as wife and mother.

\section{Hygiene and Aesthetics}

In some societies, the clitoris is considered unpleasant to both sight and touch and it is a sign of maturity when a woman's "ugly genitalia" have been removed (21). Certain societies believe that female circumcision maintains good mental and physical health in a woman (3). Though once shared by western physicians, belief in the health benefits of 
clitoridectomy have been dispelled (see above). On the contrary, there are in fact significant medical complications (see below).

Having examined the four main factors why female circumcision continues to thrive in certain societies, it is still not clear why the custom has persisted given that many of these factors have either disappeared or are now given little or no credibility. What then are the possible explanations for the continued existence of female circumcision?

Historically women have been persuaded to see their sexual impulses in terms of what suits men. This suggestion must be considered in the context of the total economic and social structure of the societies concerned. For example, marriage has traditionally been, and continues to be, the only secure future for a woman in certain communities of Africa, the Middle East, and Asia. In many of these societies, failing to excise one's daughter is to practically ensure her ruination, since no one would marry an uncircumcised woman. It is still believed that the more severe the procedure, the less the risk that the girl will disgrace her family $(3,14)$.

Second, female circumcision is arguably an irreplaceable source of revenue for the operators who are mostly older women. Only a very limited number of roles are open to women living in rural areas of Africa, thus, to put an end to this practice would invariably put an end to an otherwise profitable, centuries old business.

Third, older women themselves perpetrate the practice with much zeal having themselves previously undergone the same suffering. Senior women possess a deep conviction that in upholding and enforcing tradition, they hold together the fabric of a society that must, at whatever costs, be defended against external threats.

Fourth, since genital mutilations are not generally visible, health education programs have not been directed towards this practice. The scarcity of data showing the distress and physical damage of this practice makes it difficult to convince people of the urgency in dealing with the issue. Furthermore, the private nature of the practice and the taboo surrounding talk of genitals and sexuality discourages open discussion about female circumcision.

Fifth, because of the destructive effects of colonialism in Africa, western efforts on the part of missionaries or colonial administrators to eliminate female circumcision have been largely unsuccessful. Fears of a weakening of traditional customs as well as of the ill effects of western influences seem to be at the root of the resistance to change.
FEMALE CIRCUMCISION, MALE CIRCUMCISION, AND OTHER NON-THERAPEUTIC PRACTICES

The debate as to the similarities and differences between female and male circumcision has been ongoing for some time now, and it is valuable in reconsidering how we view each of these practices.

The major difference between female and male circumcision is the degree of mutilation. The extent of female circumcision is variable (see Box 1) but, nonetheless, the procedure is usually more risky, more painful, takes longer to heal, and has greater permanent repercussions than male circumcision. The immediate complications of female circumcision include hemorrhage, infection, and urinary retention, which if left untreated can be fatal (2,22-25). Long-term complications are also common especially for women who have been infibulated. Blocking of the urethral or vaginal opening by scar tissue can lead to a build up of urine and menstrual blood, which in turn can cause chronic pelvic and urinary tract infections $(24,25)$. Female circumcision can also cause obstetric complications $(22,25,26)$ and may increase sexual transmission of the human immunodeficiency virus (27). Furthermore, it has profound effects on sexuality and intercourse (3).

Male circumcision is usually seen to be less harmful, but advocates against it claim that this procedure can also have long-term effects including meatal stenosis (constricted urinary opening), recurrent urethritis, progressive loss of sensitivity from keratinization, tight or painful erections from excessive skin loss, and various degrees of sexual dysfunction (28). In addition, psychological dysfunction such as feelings of parental violation, mutilation, betrayal or low self-esteem from a lack of natural wholeness have been reported, though this is can also be true for female circumcision.

Despite differences in the extent of their harmful effects, neither female nor male circumcision have clear therapeutic benefits. Claims have been made that male circumcision decreases the risk of penile cancer, cervical cancer (in sexual partners), urinary tract infection, and sexual transmitted diseases while improving overall hygiene. Even if these claims were true (and there is conflicting evidence suggesting they are not), the risk reduction is most likely trivial compared to that achieved by using condoms or maintaining good foreskin hygiene, meaning that routine neonatal circumcision should not necessarily be the norm (for reviews, see 29-34).

While most would agree that female circumcision is driven by social conformity, few stop to consider whether the same pressures may be at work in the case of male circumcision. At least in certain parts of the 
world (particularly North America), parents are under pressure from society to have their sons circumcised. It is not clear whether their decision is made with proper understanding and appreciation of the procedure. It is clear that cultural, social and historical perspectives around infant circumcision influence physicians and parents; this amounts to indirect coercion. If the same social forces are at work in the case of both female and male circumcision, why then is one practice more socially acceptable than the other?

Female circumcision is by no means the only practice conducted on women for non-therapeutic purposes. Take for instance those practices that have arisen out of the western world's obsession with physical appearance, namely, breast implants, liposuction, stomach stapling, collagen lip implants, face freezing techniques, face-lifts, rib-removal and other forms of cosmetic surgery. The driving force behind all of these practices is social pressure or, stated more aggressively, social oppression.

From an ethical and legal point of view, any move to apply criminal sanctions to female circumcision must be met with similar actions to apply criminal sanctions to male circumcision and other "unnecessary" surgical procedures because these practices are based on the same underlying principles.

\section{THE MEDICAL PROFESSION'S OPPOSITION TO FEMALE CIRCUMCISION}

A number of reasons have been cited to explain the medical profession's opposition to female circumcision. One reason is that physicians should not perform unnecessary procedures even when requested to do so (35). This stems from the Hippocratic Oath's credo of first do no harm. However, if this is the view of the medical profession, then practices such as cosmetic surgery for purely aesthetic purposes, as described above, should similarly be condemned by the medical profession and should also be prohibited by law.

Another reason offered for the medical profession's opposition to female circumcision is that this practice is nothing more than mutilation which is never permitted in the name of medicine (35). Yet, where does this statement then place male circumcision, a practice that arguably has no medical value and could also be classified as mutilation? Moreover, unnecessary cosmetic surgery could be considered mutilation. In fact, it has been argued that the majority of episiotomies are unnecessary and could be considered another form of female genital mutilation (36).

A further reason that has been offered is that consent to the practice of female circumcision can never be given freely because of social pressures (35). Once again, however, if we subscribe to this reasoning, we would have to condemn other practices such as breast implants since many women who undergo these procedures are usually doing so as a result of inappropriate societal influence that pushes them to look a certain way. It has also been argued that consent for male circumcision by parents is neither properly informed nor purely voluntary. In short, the singling out of female circumcision from other similar procedures cannot be justified.

\section{INTERNATIONAL RESPONSE AND ACTION}

Female circumcision raises a number of human rights issues including the rights of women, the rights of children, the right to good health and the right to development (2). Because female circumcision transcends geopolitical borders, it has become an international issue.

The United Nations have been playing a leading role in formulating and coordinating actions against female circumcision $(1,2)$. For instance, in 1984, the InterAfrican Committee (IAC) on Traditional Practices Affecting the Health of Women and Children was formed by delegates to a conference held in Dakar, Senegal. The IAC believes in a soft approach to the abolition of female circumcision and, in addition to the support of the World Health Organization (WHO) and the United Nations Children's Fund (UNICEF), has gained the support of some of the African ruling elite. Its national chapters in Africa conduct information campaigns in Africa showing the harmful effects of traditional practices. Despite the fact that many nations have ratified conventions that lay down international standards in relation to female circumcision, the lack of political will to enforce these conventions has meant that these standards are seldom upheld (see below).

In the African context, most anti-circumcision laws were passed by the colonial powers, which looked down upon the indigenous cultures with contempt. These laws were blanket laws aimed at criminalizing a host of customary or cultural practices perceived by the imperialists as "barbaric". Today these laws have proved to be ineffective and serve as "dead letter laws" with no precise parameters for application. Most African nations have been independent for several decades now and it is necessary to re-assess the relationship between Governments and their people on this question. Furthermore, in the post-independence era, only a few African countries have specific legislation against female circumcision; these include Sudan, Egypt, the Ivory Coast, and Burkina Faso.

So long as a majority of the population in practicing nations continue to believe that female circumcision is a perfectly legitimate practice and serves the common good, legal sanctions that incriminate practitioners and 
families may be counterproductive. Indeed, criminal sanctions and regulations are effective only once a substantial body of public opinion has been raised against the practice (37). Education is fundamental in changing public opinion, as well as in offering reasonable alternatives to female circumcision that still accomplish some of its social functions. In Kenya, for example, a ceremony similar to a "circumcision ritual" has been set up in which twenty five mother-daughter pairs take part in a six day ceremony during which the girls are taught the importance of womanhood and the responsibilities it carries with it. The girls are considered women at the end of the six days, not because of any physical circumcision, but because of the "secret" knowledge they attain. The ceremony is known as Ntanira na Mugambo which literally means "circumcision through words" (38).

In western countries, especially those with large immigrant populations, the issue has gained legislative recognition and action. Countries such as Canada (39), the United States (40) the United Kingdom, Sweden, Switzerland, Australia and France have criminalized the practice. In Canada, female genital "mutilation" is condoned only where it can be proved to be of benefit to the physical health of the person, or where it will restore the person's reproductive functions or sexual appearance (39). Further, to be valid, the person must be at least eighteen years of age and there must be no resulting bodily harm.

Interestingly, the implication of this law is that interventions of this nature must only take place for therapeutic purposes. If we were to apply this law to male circumcision (which, in the present wording, it clearly does not), then male circumcision might also be outlawed for being non-therapeutic in nature.

\section{THE ROLE OF LAW}

Is the use of criminal law appropriate in solving the male and female circumcision debate? Would the threat of criminal sanctions necessarily restrain the practice of female circumcision or even male circumcision in light of the social realities and cultural diversities? Can such action be interpreted as a tool for change in social behavior?

According the great jurist Roscoe Pound (41), "Enforcement of law is not a problem in homogenous societies where the formal law merely codifies widely shared and observed practices." Therefore, when a society is not homogeneous and a subset of citizens supports a certain behavior, the simple act of criminalizing that behavior may not necessarily result in a reduction of its practice. Moreover, in some instances, legal enforcement has actually led to the exacerbation of the original problem. A good example is abortion where, despite its prohibition in certain jurisdictions, the practice did not wither away but instead persisted, albeit underground, causing women to undergo this procedure in unhygienic conditions where the risks associated with the procedure were increased manifoldly (42).

Given the differences in attitudes towards female circumcision, it is unlikely that a purely legal solution to the problem of female circumcision, such as a prohibition on its practice, will bring this practice to a halt. Instead, a great deal of work needs to be done in educating the public as well as the affected populations that circumcision is a practice that has outlived its purpose. Rigorous, culture-sensitive campaigns are needed if the attitude of the populations practicing circumcision is to be changed.

Multicultural countries such as the US and Canada should emulate what Governments in some African countries are doing. They should launch public education campaigns among affected immigrant populations in their countries. It is only once the target populations appreciate that female circumcision is harmful that there will be sufficient justification in laying criminal sanctions against the practice. The justification will in fact be the strong consensus among the affected populations that the practice is indeed harmful. Using the law may be a political, emotional and even a moral response on the part of western governments, however, in reality it does nothing more than to increase hostility and defiance among the people who currently practice female circumcision. We must keep this in mind at all times, and only use the force of criminal law as a last resort and with the utmost caution.

\section{ACKNOWLEDGEMENTS}

The author would like to express her profound gratitude to Professor Margaret Somerville, Faculties of Law and Medicine, McGill University, for her insightful suggestions, comments and criticisms of this paper. She is also grateful to the Institute of Human Values, MUSC for all its assistance, both material and moral. The author would finally like to thank Eleni Yiannakis and Yolande Makolo for their helpful remarks and for being willing to engage in discussions with the author on some of the more controversial aspects of this paper.

\section{REFERENCES}

1. World Health Organization. Female genital mutilation: report of a WHO technical working group, Geneva, 17-19 July 1995. http://www.who.int/frh-whd/FGM/Technical_Working_ Group/English/Technical_Working_Group.htm. 1996.

2. World Health Organization. Female genital mutilation: information pack. http://www.who.int/frh-whd/FGM/infopack/ English/fgm_infopack.htm. 1999. 
3. Lightfoot-Klein H. Prisoners of ritual: an odyssey into female genital circumcision in Africa. New York: Harrington Press Inc.; 1989.

4. Giorgis BW. Female circumcision. Addis Ababa: United Nations Economic Commission for Africa, African Training and Research Center for Women and Association of African Women for Research and Development; 1981.

5. Shaalan M. Clitoris envy: a psycho-dynamic construct instrumental in female circumcision. Alexandria: WHO/EMRO Technical Publication; 1982.

6. Barker-Benfield B. Sexual surgery in late-nineteenth century America. International Journal of Health Services 5: 279-288; 1975.

7. Black J. Female genital mutilation: a comtemporary issue, and a Victorian obsession. Journal of the Royal Society of Medicine 90: 402-405; 1997.

8. Wallerstein E. Circumcision: an American health fallacy. New York: Springer Publishing Co.; 1980.

9. Fraser A. Female genital mutilation and Baker Brown. Journal of the Royal Society of Medicine 90: 586-587; 1997.

10. Money J. The destroying angel. New York: Prometheus Books; 1985.

11. Spitz R. Authority and masturbation. Psychoanalytic Quarterly 21: 503; 1952.

12. Bullough V, Bullough B. Sins, sickness and sanity. New York: The American Library; 1977.

13. Epelboin S, Epelboin A. Special report: female circumcision. People 6: 24-29; 1979.

14. Hosken FP. The Hosken Report, genital and sexual mutilation of females. Lexington, MA: International Network News; 1982.

15. Oduntan $\mathrm{O}$, Onadeko $\mathrm{M}$. Female circumcision in Nigeria. Senegal: WHO/EMRO Technical Publication; 1984.

16. Hayes RO. Female genital mutilation, fertility control, women's roles and the patrilineage in modern Sudan, a functional analysis. American Ethnologist 2: 627-637; 1975.

17. Ammar H. Growing up in an Egyptian village. London: Routledge and Kegan Paul; 1954.

18. Hansen H H. Clitoridectomy: female circumcision in Egypt. Folk 14/15: 15-26; 1972/3.

19. Abu-Sahlieh SA. To mutilate in the name of Jehovah or Allah: legitimization of male and female circumcision. Medicine and Law 13: 575-622; 1994.

20. Alibhai SM. Female circumcision not in Qur'an. Canadian Medical Association Journal 152: 1190; 1995.

21. Assaad MB. Female circumcision in Egypt: social implications, current research and prospects for change. Studies in Family Planning 11: 3-16; 1980.

22. Aziz FA. Gynecologic and obstetric complications of female circumcision. International Journal of Gynaecology and Obstetrics 17: 560-563; 1980.

23. Dirie MA, Lindmark G. A hospital study of the complications of female circumcision. Tropical Doctor 21: 146-148; 1991

24. Dirie MA, Lindmark G. The risk of medical complications after female circumcision. East African Medical Journal 69: 479-482; 1992.

25. Arbesman M, Kahler L, Buck GM. Assesment of the impact of female circumcision on the gynecological, genitourinary and obstetrical health problems of women in Somalia: literature review and case series. Women and Health 20: 27-42; 1993.

26. De Silva S. Obstetric sequelae of female circumcision. European Journal of Obstetrics, Gynecology, and Reproductive Biology 32: 233-240; 1989.

27. Hrdy DB. Cultural practices contributing to the transmission of human immunodeficiency virus in Africa. Review of Infectious Diseases 9: 1109-1119; 1987.

28. Marshall F. Complications of circumcision. British Journal of Surgery 80: 1231-1236; 1993.

29. Grossman E, Posner N. Surgical circumcision of neonates, a history of its development. Obstetrics and Gynecology 58: 241246; 1981.

30. Poland RL. The question of routine neonatal circumcision. New England Journal of Medicine 322: 1312-1315; 1990.

31. Robson WL, Leung AK. The circumcision question. Postgraduate Medicine 91: 237-244; 1992.

32. Moses S, Plummer FA, Bradley JE, et al. The association between lack of male circumcision and risk for HIV infection: a review of the epidemiological data. Sexually Transmitted Diseases 21: 201-210; 1994.

33. Harbinson M. The arguments for and against circumcision. Nursing Standard 11: 42-47; 1997.

34. Van Howe RS. Circumcision and HIV infection: review of the literature and meta-analysis. International Journal of STD and AIDS 10: 8-16; 1999.

35. Schwartz R. Multiculturalism, medicine and the limits of autonomy: the practice of female circumcision. Cambridge Quarterly of Healthcare Ethics 3: 431-441; 1994.

36. Wagner M. Episiotomy: a form of genital mutilation. Lancet 353: 1977-1978; 1999.

37. Dorendo E, Elworthy S. Female genital mutilation: proposals for change. London: A Minority Rights Group, International Report - Manchester Free Press; 1992.

38. Chelala C. An alternative way to stop female genital mutilation. Lancet 352: 126; 1998

39. Criminal Code, R.S.C. 1992, c. C-46, s. 268 (3), s. 268 (4).

40. Key FL. Female circumcision/female genital mutilation in the United States: legislation and its implications for health providers. Journal of the American Medical Women's Association 52: 179-180; 1997.

41. Pound R. The limits of effective legal action. American Bar Association Journal 3: 55-70; 1917.

42. Government of Canada. Report of the committee on the operation of the abortion law - Badgeley Report. Ottawa: Minister of Supply and Services Canada; 1977.

Angela Wasunna holds an Honours Bachelor of Laws Degree (LLB) from the University of Nairobi, Kenya and is expected to receive a Master of Laws Degree (LLM) from McGill University, Montreal, Canada. She is currently in the Graduate Law Program at Harvard Law School, Cambridge, MA, United States. 